\title{
Review of effects of anti-VEGF treatment on refractive error
}

This article was published in the following Dove Press journal:

Eye and Brain

I5 June 2016

Number of times this article has been viewed

\section{Helen A Mintz-Hittner ${ }^{1,2}$ Megan M Geloneck ${ }^{1,2}$}

'Ruiz Department of Ophthalmology and Visual Science, McGovern Medical School at UTHealth, ${ }^{2} \mathrm{WT}$ and Louise J Moran Pediatric Eye Clinic (affiliate of Robert Cizik Eye Clinic), Houston, TX, USA
Correspondence: Helen A Mintz-Hittner Ruiz Department of Ophthalmology and Visual Science, McGovern Medical School at UTHealth, 6400 Fannin Street - Suite I800, Houston, TX 77030-I526, USA

Tel +l 7I3 5595277

Fax +I 7I3 5595290

Email Helen.A.Mintz-Hittner@uth.tmc.edu
Abstract: To examine the effect of anti-vascular endothelial growth factor (anti-VEGF) agents on refractive error in the setting of retinopathy of prematurity (ROP) through a review of the literature, a PubMed search was performed of appropriate search terms, and the results of all relevant studies were extracted and compiled. Eleven relevant articles were identified in the literature, totaling 466 eyes, treated with varied anti-VEGF agents (bevacizumab, ranibizumab, and aflibercept) with mean spherical equivalent refractions ranging from $+0.75 \mathrm{D}$ to $-3.57 \mathrm{D}$, with prevalence of high myopia ranging from 0 to $35 \%$. Anti-VEGF monotherapy for ROP leads to low levels of myopia, and there may be a differential effect of specific anti-VEGF agents utilized on refractive outcomes.

Keywords: retinopathy of prematurity, ROP, refraction, myopia, bevacizumab, ranibizumab, aflibercept

\section{Introduction}

Advances in treatment for retinopathy of prematurity (ROP) are allowing better anatomical and functional outcomes, with further prevention of blindness from retinal detachment. Perhaps the most recent addition to the ROP-treatment armamentarium are anti-VEGF agents. Anti-VEGF agents have considerable clinical benefits, including reduction in the rate of high and very high myopia following treatment, compared with peripheral ablation. ${ }^{1}$

Previously, as seen following cryotherapy and laser ablative therapy, these eyes would often develop high and very high myopia, which was attributed to the severity of ROP and not to the treatment modality itself. ${ }^{2-4}$ Similar, though much lower degrees of myopia, termed "myopia of prematurity", are also seen in children born prematurely without ROP, ${ }^{2,5-8}$ as well as in children with ROP that spontaneously regresses, called "myopia of spontaneously regressed ROP". ${ }^{2,5-12}$ In all of these cases, the myopia is nonaxial in nature with a steepened cornea, shallow anterior chamber, and thickened crystalline lens. ${ }^{9,10,13-15}$ These features are thought to be due to an arrested state of development of the immature eye. ${ }^{12,16}$

The myopia associated with prematurity and ROP develops along a spectrum, with myopia of prematurity of the lowest order, followed by myopia of spontaneously regressed ROP, with myopia of laser ablation creating the highest myopia. ${ }^{1-12,16-19}$ These factors alone are suggestive of an effect of severity of ROP on the development of myopia. However, with increasing research and recent data, ${ }^{1,16-19}$ it seems the myopia seen in the face of prematurity and ROP is multifactorial in etiology, with three main causative 
factors: 1) prematurity, 2) the severity of ROP, and 3) changes related to the treatment administered for ROP (ie, peripheral retinal ablation or anti-VEGF administration). Peripheral retinal ablation causing increased myopia has been described in several reports, ${ }^{16-19}$ including a recent report of the refractive outcomes of the BEAT-ROP clinical trial at age 2.5 years. ${ }^{1}$ The purpose of this review is to investigate the contributions of these causative factors to the resulting refractive error seen in children treated by anti-VEGF agents for ROP.

\section{Materials and methods}

A PubMed search was performed of several combinations of the following search terms: retinopathy of prematurity, ROP, refraction, refractive error, myopia, bevacizumab, ranibizumab, aflibercept, pegaptanib, anti-vascular endothelial growth factor, and anti-VEGF. The last search update was performed on January 13, 2016. The reference list of each identified article was also reviewed to ensure completeness. Extracted information from each relevant article included the first author's name, year of publication, country in which the study was conducted, average gestational age of each cohort, average birth weight of each cohort, percentage of eyes treated for zone I ROP, specific treatment modalities utilized, average adjusted age (gestational age + number of weeks of life) at time of treatment, average age at time of refraction, average spherical equivalent (SE) refractive error in diopters, prevalence of myopia $(\mathrm{SE}>-0.25 \mathrm{D})$, and prevalence of high myopia $(\mathrm{SE}>-5 \mathrm{D})$.

\section{Results}

After a thorough PubMed review, eleven articles ${ }^{1,20-29}$ were identified relevant to the topic. In total, this amounted to 466 eyes (the number of infants was not consistently reported) treated with anti-VEGF agents for ROP: 378 eyes with intravitreal bevacizumab monotherapy (dosage ranging from 0.375 to $1.25 \mathrm{mg}$, with the majority administered $0.625 \mathrm{mg}$ ), 31 eyes with intravitreal ranibizumab monotherapy $(0.25 \mathrm{mg})$, and 26 eyes with intravitreal aflibercept monotherapy $(1 \mathrm{mg})$. The extracted information from each article is compiled in Table 1. The average SE refractive error reported after antiVEGF monotherapy ranged from $+0.75 \mathrm{D}$ to $-3.57 \mathrm{D}$. The average age at time of refraction in these studies ranged from 11.4 months to 5 years.

\section{Discussion}

The use of anti-VEGF agents in the treatment of ROP is being increasingly studied and utilized. The average SE

Table I Reports of refractive error after the use of anti-vascular endothelial growth factor agents for the treatment of retinopathy of prematurity

\begin{tabular}{|c|c|c|c|c|c|c|c|c|c|}
\hline Study & Location & $\begin{array}{l}\text { Mean GA } \\
\text { (weeks) }\end{array}$ & $\begin{array}{l}\text { Mean BW } \\
\text { (g) }\end{array}$ & $\begin{array}{l}\text { Mean AA } \\
\text { at Tx } \\
\text { (weeks) }\end{array}$ & $\begin{array}{l}\text { Refracted } \\
\text { eyes, } n\end{array}$ & $\begin{array}{l}\text { Refraction } \\
\text { age } \\
\text { (months) }\end{array}$ & $\begin{array}{l}\text { Anti-VEGF, } \\
\text { dose (mg) }\end{array}$ & $\begin{array}{l}\text { Mean SE } \pm \text { SD (D), } \\
\text { anti-VEGF Tx }\end{array}$ & $\begin{array}{l}\text { Mean SE } \pm \text { SD (D), } \\
\text { laser Tx }\end{array}$ \\
\hline Wu et $\mathrm{al}^{20}$ & Taiwan & 26.3 IVB & 930.I IVB & 36.6 IVB & $\begin{array}{l}53 \text { IVB } \\
\text { I4 IVB + CLT }\end{array}$ & 17.8 & IVB, 0.625 & $-0.1 \pm 1.8$ & NA \\
\hline $\begin{array}{l}\text { Martínez- } \\
\text { Castellanos } \\
\text { et } \mathrm{al}^{21}\end{array}$ & Mexico & 29.3 IVB & $\mathrm{I}, 233.3 \mathrm{IVB}$ & 25.2 IVB & 9 IVB & 60 & IVB, 1.25 & -1.75 & NA \\
\hline $\begin{array}{l}\text { Harder } \\
\text { et al }{ }^{22}\end{array}$ & Germany & $\begin{array}{l}25.2 \text { IVB } \\
25.3 \mathrm{CLT}\end{array}$ & $\begin{array}{l}622 \mathrm{IVB} \\
717 \mathrm{CLT}\end{array}$ & $\begin{array}{l}25.2 \text { IVB } \\
25.3 \mathrm{CLT}\end{array}$ & $\begin{array}{l}23 \text { IVB } \\
26 \mathrm{CLT}\end{array}$ & 11.4 & $\begin{array}{l}\text { IVB, } 0.375 \text { or } \\
0.625\end{array}$ & $-1.04 \pm 4.24$ & $-4.4 I \pm 5.5$ \\
\hline Chen et $\mathrm{al}^{23}$ & Taiwan & 26.4 IVB & 882.2 IVB & 35 & $\begin{array}{l}40 \text { IVB } \\
\text { I7 IVB + CLT }\end{array}$ & 24 & IVB, 0.625 & $-0.98 \pm 4.05$ & IVB + CLT: -2.4 \\
\hline $\begin{array}{l}\text { Geloneck } \\
\text { et al' }\end{array}$ & USA & $\begin{array}{l}24.4 \text { IVB } \\
24.2 \mathrm{CLT}\end{array}$ & $\begin{array}{l}\text { 652.I IVB } \\
669.3 \mathrm{CLT}\end{array}$ & $\begin{array}{l}\text { 35.I IVB } \\
34.8 \mathrm{CLT}\end{array}$ & $\begin{array}{l}\text { IIO IVB } \\
\text { I0I CLT }\end{array}$ & $\begin{array}{l}30 \mathrm{IVB} \\
30 \mathrm{CLT}\end{array}$ & IVB, 0.625 & $\begin{array}{l}\text { Zone I: }-1.5 I \pm 3.42 \\
\text { Zone II: }-0.58 \pm 2.53\end{array}$ & $\begin{array}{l}\text { Zone I: }-8.44 \pm 7.57 \\
\text { Zone II: }-5.83 \pm 5.87\end{array}$ \\
\hline $\begin{array}{l}\text { Salman and } \\
\text { Said }^{24}\end{array}$ & Egypt & 26.3 IVA & 99I IVA & NA & 26 IVA & 12 & IVA, I & 0.75 & NA \\
\hline Isaac et a $\left.\right|^{25}$ & Canada & $\begin{array}{l}25.2 \text { IVB } \\
25 \mathrm{CLT}\end{array}$ & $\begin{array}{l}722 \text { IVB } \\
674 \mathrm{CLT}\end{array}$ & $\begin{array}{l}37.6 \mathrm{IVB} \\
36.7 \mathrm{CLT}\end{array}$ & $\begin{array}{l}23 \text { IVB } \\
22 \mathrm{CLT}\end{array}$ & 12 & IVB, 0.625 & $-3.57 \pm 6.19$ & $-6.39 \pm 4.4 I$ \\
\hline Kuo et $\mathrm{al}^{26}$ & Taiwan & NA & NA & NA & $\begin{array}{l}\text { I4 IVB } \\
\text { I5 CLT }\end{array}$ & 36 & NA & $-1.53 \pm 2.2$ & $-1.7 \mid \pm 1.27$ \\
\hline Chen et $\mathrm{al}^{27}$ & Taiwan & $\begin{array}{l}26.5 \text { IVB } \\
26.2 \text { IVR }\end{array}$ & $\begin{array}{l}\text { 869.1 IVB } \\
848.8 \text { IVR }\end{array}$ & $\begin{array}{l}36.8 \text { IVB } \\
36.4 \text { IVR }\end{array}$ & $\begin{array}{l}4 I I V B \\
3 I I V R\end{array}$ & 12 & $\begin{array}{l}\text { IVB, } 0.625 \\
\text { IVR, } 0.25\end{array}$ & $\begin{array}{l}-0.3 \text { IVB } \\
+0.1 \text { IVR }\end{array}$ & $\mathrm{iVB}+\mathrm{CLT}:-2.4$ \\
\hline $\begin{array}{l}\text { Hwang } \\
\text { et } \mathrm{al}^{28}\end{array}$ & USA & $\begin{array}{l}24.2 \text { IVB } \\
24.8 \mathrm{CLT}\end{array}$ & $\begin{array}{l}\text { 668.I IVB } \\
701.4 \mathrm{CLT}\end{array}$ & $\begin{array}{l}\text { 35.I IVB } \\
\text { 36.1 CLT }\end{array}$ & $\begin{array}{l}22 \mathrm{IVB} \\
32 \mathrm{CLT}\end{array}$ & $\begin{array}{l}22.4 \text { IVB } \\
\text { 37.I CLT }\end{array}$ & IVB, 0.625 & $\begin{array}{l}-2.4 \text { (zone I, }-3.7 ; \\
\text { zone II, } 0.6)\end{array}$ & $\begin{array}{l}-5.3 \text { (zone I, -10.I; } \\
\text { zone II, -4.7) }\end{array}$ \\
\hline $\begin{array}{l}\text { Gunay } \\
\text { et al }{ }^{29}\end{array}$ & Brazil & $\begin{array}{l}26.4 \text { IVB } \\
27.3 \mathrm{CLT}\end{array}$ & $\begin{array}{l}901.4 \text { IVB } \\
941 \mathrm{CLT}\end{array}$ & $\begin{array}{l}\text { 34.0 IVB } \\
33.9 \mathrm{CLT}\end{array}$ & $\begin{array}{l}43 \mathrm{IVB} \\
35 \mathrm{CLT}\end{array}$ & 24 & IVB, 0.625 & $0.42 \pm 3.42$ & $-6.66 \pm 4.96$ \\
\hline
\end{tabular}

Abbreviations: CLT, conventional laser therapy; IVB, intravitreal bevacizumab; IVR, intravitreal ranibizumab; IVA, intravitreal aflibercept; GA, gestational age; BW, birth weight; AA, adjusted age; Tx, treatment; SD, standard deviation; SE, spherical equivalent refractive error; NA, not available. 
Table 2 Cycloplegic retinoscopic refractive error at age 2.5 years in the Bevacizumab Eliminates the Angiogenic Threat for Retinopathy of Prematurity clinical trial'

\begin{tabular}{|c|c|c|c|c|}
\hline \multirow{2}{*}{$\begin{array}{l}\text { Spherical equivalent } \\
\text { refractions, D }\end{array}$} & \multicolumn{2}{|c|}{ Intravitreal bevacizumab } & \multicolumn{2}{|l|}{ Laser } \\
\hline & Without recurrence & With recurrence & Without recurrence & With recurrence \\
\hline Zone I (87 eyes)* & 50 eyes & 2 eyes & 26 eyes & 9 eyes \\
\hline Mean (SD) & $-1.36(3.34)$ & $-5.25(4.6)$ & $-7.34(7.44)$ & $-11.61(7.42)$ \\
\hline Median (range) & $-0.50(-8$ to 6$)$ & $-5.25(-8.5$ to -2$)$ & $-4.69(-24.88$ to 2$)$ & $-10(-22$ to 0.75$)$ \\
\hline Zone II posterior (I 24 eyes)** & 56 eyes & 2 eyes & 58 eyes & 8 eyes \\
\hline Mean (SD) & $-0.63(2.56)$ & $0.88(0)$ & $-5.2(5.77)$ & $-10.42(4.58)$ \\
\hline Median (range) & $0(-13$ to 2.5$)$ & $0.88(0.88-0.88)$ & $-4(-19$ to 3.5$)$ & $-11.5(-15$ to -2.63$)$ \\
\hline
\end{tabular}

Notes: *For zone I, the mean (SD) spherical equivalent refractions for the intravitreal bevacizumab group were $-1.5 \mathrm{I}$ (3.42) D (median [range], -0.56 [-8.56 to 6] D), and for the laser group were -8.44 (7.57) D (median [range], -8.00 [ -24.88 to 2] $D)(P<0.00$ I); ** for zone II posterior, the mean (SD) spherical equivalent refractions for the intravitreal bevacizumab group were -0.58 (2.53) D (median [range], 0 [ -13 to 2.5] D), and for the laser group were -5.83 (5.87) D (median [range], -4.88 [ -19 to 3.50 ] D) $(P<0.00$ I). Reproduced with permission from JAMA Ophthalmol. 2014;132(II):I327-1333. Copyright@20 I4 American Medical Association. All rights reserved.'

Abbreviation: SD, standard deviation.

refractive error following the administration of anti-VEGF agents is in the low-myopia range (mean ranging from +0.1 to $-3.57 \mathrm{D})$ ) $^{1,20-29}$ There is some suggestion, however, that different anti-VEGF agents may yield different prevalence of high myopia (defined as $\mathrm{SE} \leq-5 \mathrm{D}$ ), with intravitreal bevacizumab yielding high myopia in $8 \%-35 \%$ of eyes ${ }^{1,20-23,25-27}$ versus in 0 following intravitreal ranibizumab treatment. ${ }^{27}$ However, more data are needed to better establish any differential effects on refractive error.

In the BEAT-ROP study, infants with stage $3+$ or aggressive posterior ROP in zone I or zone II posterior were randomized to receive peripheral retinal laser ablation or intravitreal bevacizumab monotherapy. ${ }^{30}$ In the 2.5 -year refractive outcome results of the BEAT-ROP cohort, eyes matched for severity of ROP receiving anti-VEGF therapy were found to have significantly lower myopia on average than those receiving peripheral laser ablation (Table 2). ${ }^{1}$ Mean SE refractions for those with zone I disease were $-1.51 \pm 3.42 \mathrm{D}$ in eyes treated with anti-VEGF and $-8.44 \pm 7.57 \mathrm{D}$ in eyes that received laser treatment. Mean SE refractions for those with zone II posterior disease were $-0.58 \pm 2.53 \mathrm{D}$ after treatment with anti-VEGF and $-5.83 \pm 5.87 \mathrm{D}$ after treatment with retinal laser. Specifically, very high myopia ( $\geq-8 \mathrm{D}$ ) occurred in significantly fewer eyes treated with anti-VEGF ( $3.8 \%$ zone I, $1.7 \%$ zone II posterior) than in those treated with peripheral laser (51.4\% zone I, 36.4\% zone II posterior). These findings suggest a possible significant contribution of laser ablation to the increased myopia seen in these infants (Figures 1 and 2).

In eyes treated for recurrence of ROP with additional antiVEGF, as was done in the BEAT-ROP clinical trial, there was a further increase in myopia. This increased myopia was also seen in the control arm (laser ablation) of BEAT-ROP. ${ }^{1}$ This increased myopia in eyes treated for recurrence of ROP is likely due to two of the three main etiological factors responsible for myopia in the premature population: increase in sever- ity of ROP, and changes related to the treatment administered. Recurrence of ROP causes an equivalent reexposure to the disease process in both arms, and should therefore be expected to cause an equivalent increase in resultant myopia. However, there was a much higher incidence of very high myopia in eyes receiving additional laser (76.5\%) for recurrence than in those receiving additional anti-VEGF (25\%), suggestive of an added contribution from the treatment modality itself. ${ }^{1}$ Increase in myopia and high myopia (defined in this study as $\mathrm{SE} \leq-5 \mathrm{D})$ in eyes $(\mathrm{n}=17)$ treated with laser for recurrence following initial anti-VEGF therapy was also seen in a recent study by Chen et al, suggesting again the role of both severity and possibly treatment modality in the development of increased myopia in eyes treated for recurrent ROP. ${ }^{23}$

To better understand the impact of the refractive outcomes following anti-VEGF therapy, it is necessary to

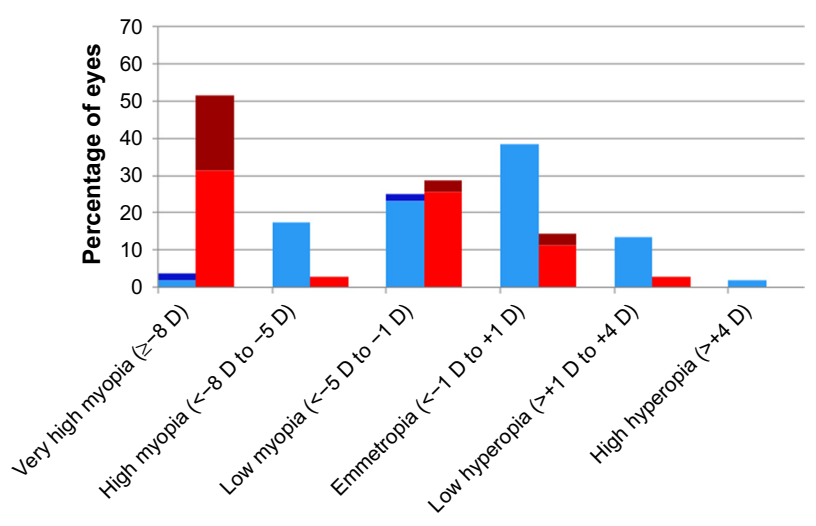

Figure I Zone I distribution of refractive error by treatment modality.

Notes: Distribution of spherical equivalent refractive error at age 2.5 years in eyes that received treatment for stage 3+ retinopathy of prematurity or aggressive posterior retinopathy of prematurity in the Bevacizumab Eliminates the Angiogenic Threat for Retinopathy of Prematurity clinical trial.' Data presented according to treatment modality: red, laser without recurrence; brown, laser with recurrence; light blue, intravitreal bevacizumab without recurrence; dark blue, intravitreal bevacizumab with recurrence. Reproduced with permission from JAMA Ophthalmol. 2014;132(II):1327-1333. Copyright @2014 American Medical Association. All rights reserved.' 


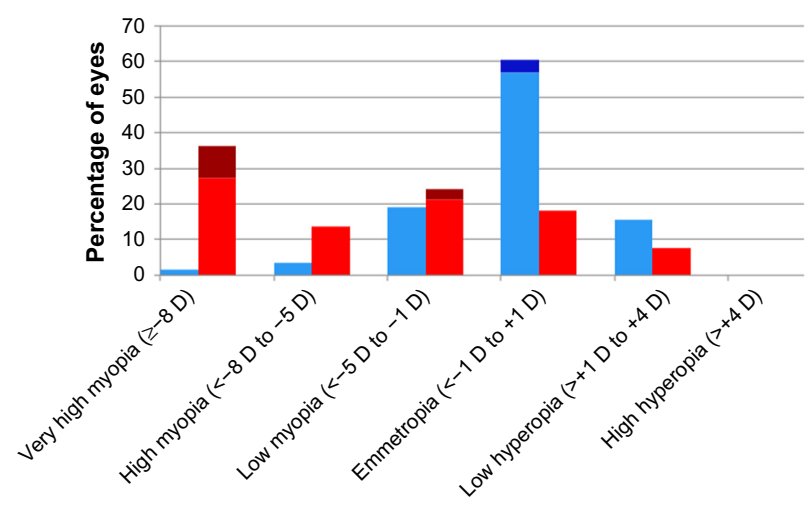

Figure 2 Zone II posterior distribution of refractive error by treatment modality. Notes: Distribution of spherical equivalent refractive error at age 2.5 years in eyes that received treatment for stage $3+$ retinopathy of prematurity or aggressive posterior retinopathy of prematurity in the Bevacizumab Eliminates the Angiogenic Threat for Retinopathy of Prematurity clinical trial.' Data presented according to treatment modality: red, laser without recurrence; brown, laser with recurrence; light blue, intravitreal bevacizumab without recurrence; dark blue, intravitreal bevacizumab with recurrence. Reproduced with permission from JAMA Ophthalmol. 2014;132(II):13271333. Copyright (C) 2014 American Medical Association. All rights reserved.'

appreciate them in the setting of the current standard of care for ROP derived from the ETROP clinical trial. ${ }^{31} \mathrm{~A}$ historical comparison of ETROP and BEAT-ROP was compiled to highlight some similarities and differences in the refractive outcomes of these studies (Figure 3). In the ETROP study, ${ }^{3,4}$ the control group (laser treatment at threshold ROP) had a slightly greater percentage of eyes with myopia of $-5 \mathrm{D}$ or higher than the experimental group (laser treatment at high-risk prethreshold ROP). The percentage of eyes with myopia of $-5 \mathrm{D}$ or greater following laser therapy in the BEAT-ROP trial (for high-risk prethreshold to threshold ROP) was between that seen following laser treatment for both the control and experimental eyes in the ETROP clinical trial. ${ }^{1}$ In contrast, the percentage of eyes with myopia of $-5 \mathrm{D}$ or greater after intravitreal bevacizumab treatment in the BEAT-ROP cohort was far less than that seen following peripheral retinal ablation. The myopia following anti-VEGF monotherapy for ROP in eyes that received intravitreal bevacizumab in the BEAT-ROP trial was similar to the myopia of spontaneously regressed ROP seen in the ETROP trial. ${ }^{1,3,4}$

Similar amounts of low myopia and a tendency for emmetropia following treatment with anti-VEGF agents were also reported in several other case series. ${ }^{20-29,32}$ Although purely speculative at this time, it is possible that intravitreal anti-VEGF agents allow for minimal disruption in the local growth-factor milieu and signaling pathways responsible for development of the anterior segment. As others have previously hypothesized, the incomplete development of the retina in prematurity with or without ROP may alter

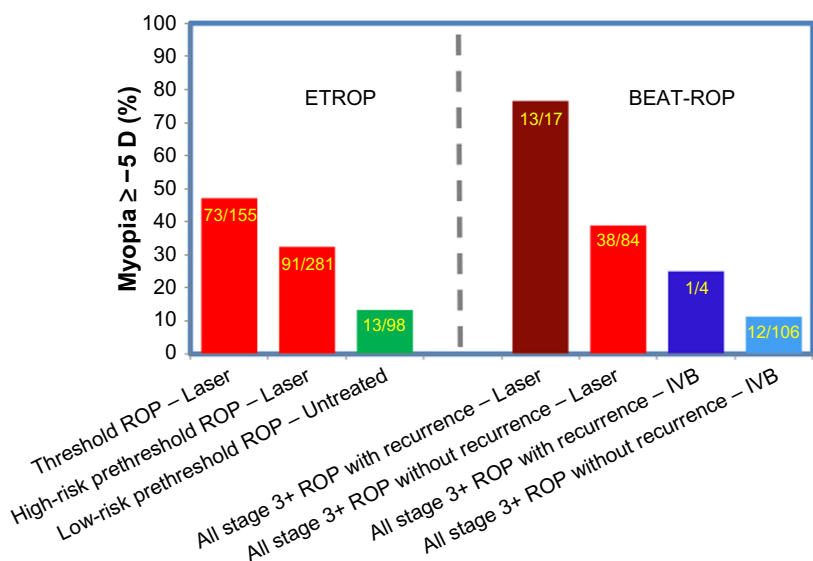

Figure 3 Percentage of eyes $\geq-5 D$ in ETROP and BEAT-ROP by ROP severity at treatment.

Notes: Percentage of eyes with myopia $\geq-5$ D in the ETROP and BEAT-ROP clinical trials at ages 3 and 2.5 years, respectively. Data presented according to ROP severity at treatment (threshold, high-risk prethreshold, low-risk prethreshold, and all stage $3+$ ) by treatment modality utilized (laser and IVB) in the respective clinical trials. Data from ETROP, ${ }^{3}$ and BEAT-ROP.'

Abbreviations: ROP, retinopathy of prematurity; IVB, intravitreal bevacizumab.

local ocular growth signals, ${ }^{12,16,33}$ which may account for the anterior-segment changes seen in myopia of prematurity and in myopia of spontaneously regressed ROP. Intravitreal bevacizumab allows for continued development of the retinal vessels beyond the neovascular ridges, while this continuation is minimal following laser ablation. ${ }^{30}$ The allowance of further migration of retinal vessels toward but not always necessarily to the ora serrata and the further maturation of photoreceptors may allow for more normal levels of the local growth factors required for proper signaling cascades in anterior-segment development. ${ }^{11,34}$ This would account for the lower amounts of myopia seen following anti-VEGF therapy. This is in contrast to the increased myopia and high myopia seen following treatment with laser, in which conceivably peripheral retinal ablation is more disruptive of the local growth-factor milieu and signaling pathways, leading to further impedance of anterior-segment development.

By potentially allowing more normal anterior-segment development in eyes treated with anti-VEGF agents, the cornea might be less steep, the anterior chamber deeper, and the lens less thickened. Thereby, these eyes may have the added benefit of also being at less risk of secondary long-term effects of high myopia, namely late angle-closure glaucoma, which is not uncommonly seen in eyes that have received prior laser therapy for ROP. ${ }^{35,36}$

Most recently, questions regarding the most appropriate anti-VEGF agent to use for the treatment of ROP have arisen and received much attention. The main two anti-VEGF agents being discussed for use in ROP, which 
have shown similar efficacy in the treatment of choroidal neovascularization in adults with age-related macular degeneration, are bevacizumab (Avastin; Genentech Inc, San Francisco, CA, USA) and ranibizumab (Lucentis; Genentech). ${ }^{37}$ These two agents differ in biochemical structure, size and half-life, with bevacizumab having the longer half-life of 20 days versus ranibizumab's half-life of 2 hours. $^{38,39}$ These differences in structure, size, and halflife are of particular interest in their systemic and ocular effects on neonates following treatment for ROP. Studies have shown systemic VEGF levels are blunted for several weeks following treatment with bevacizumab for ROP. ${ }^{40-42}$ However, this blunting of systemic VEGF is not as prolonged following treatment with intravitreal ranibizumab for ROP. Recent evidence has shown that systemic VEGF levels immediately following intravitreal ranibizumab administration for ROP are diminished (at 1 day), but this effect does not persist at 1 week or later. ${ }^{43}$

The differential ocular effects of these two anti-VEGF agents in eyes with ROP are just now being elucidated. While the efficacy in treatment of ROP (ie, regression and recurrence patterns) has been reported as similar between bevacizumab and ranibizumab, ${ }^{27}$ the refractive outcomes may differ. More high myopia was seen in eyes treated with bevacizumab than in those treated with ranibizumab at 1 year of age $(14.6 \%$ versus 0 , respectively; $P=0.03) .{ }^{27}$ Chen et al hypothesized that the longer half-life of bevacizumab may be responsible for these refractive differences, perhaps by allowing increased apoptosis of retinal structures responsible for developmental signaling cascades. ${ }^{27}$ This theory is based on a murine model, in which inhibition of VEGF receptors led to loss of Müller cells, astrocytes, and ganglion cells from the inner retina. ${ }^{44}$ While this was just a single retrospective review, it raises interest in the differential effects on anterior-segment development and subsequent refractive error, which deserve further investigation and longer-term outcome data.

\section{Conclusion}

As intravitreal anti-VEGF agents are still new in the treatment armamentarium for ROP, there are several aspects of this therapy requiring further investigation, specifically longerterm refractive and visual outcomes following anti-VEGF treatment, as well as establishment of the long-term safety and a refinement of the dose and best specific anti-VEGF agent. However, outcomes thus far have been exciting, and the lesser myopia and decreased incidence of high myopia seen following anti-VEGF treatment compared to that following retinal laser ablation is not trivial.

\section{Disclosure}

The authors report no conflicts of interests in this work.

\section{References}

1. Geloneck MM, Chuang AZ, Clark WL, et al. Refractive outcomes following bevacizumab monotherapy compared with conventional laser treatment: a randomized clinical trial. JAMA Ophthalmol. 2014;132(11):1327-1333.

2. Quinn GE, Dobson V, Kivlin J, et al. Prevalence of myopia between 3 months and $5 \frac{1}{2}$ years in preterm infants with and without retinopathy of prematurity. Ophthalmology. 1998;105(7):1292-1300.

3. Quinn GE, Dobson V, Davitt BV, et al. Progression of myopia and high myopia in the Early Treatment for Retinopathy of Prematurity study: findings to 3 years of age. Ophthalmology. 2008;115(6): 1058-1064.e1.

4. Quinn GE, Dobson V, Davitt BV, et al. Progression of myopia and high myopia in the Early Treatment for Retinopathy of Prematurity study: findings at 4 to 6 years of age. J AAPOS. 2013;17(2):124-128.

5. Nissenkorn I, Yassur Y, Mashkowski D, Sherf I, Ben-Sira I. Myopia in premature babies with and without retinopathy of prematurity. $\mathrm{Br} J$ Ophthalmol. 1983;67(3):170-173.

6. O'Connor AR, Stephenson T, Johnson A, et al. Long-term ophthalmic outcome of low birth weight children with and without retinopathy of prematurity. Pediatrics. 2002;109(1):12-18.

7. O'Connor AR, Stephenson TJ, Johnson A, Tobin MJ, Ratib S, Fielder AR. Change of refractive state and eye size in children of birth weight less than 1701 g. Br J Ophthalmol. 2006;90(4):456-460.

8. Cook A, White S, Batterbury M, Clark D. Ocular growth and refractive error development in premature infants with or without retinopathy of prematurity. Invest Ophthalmol Vis Sci. 2008;49(12):5199-5207.

9. Mintz-Hittner HA, Rhodes LM, McPherson AR. Anterior segment abnormalities in cicatricial retinopathy of prematurity. Ophthalmology. 1979;86(5):803-816.

10. Wu WC, Lin RI, Shih CP, et al. Visual acuity, optical components, and macular abnormalities in patients with a history of retinopathy of prematurity. Ophthalmology. 2012;119(9):1907-1916.

11. Lue CL, Hansen RM, Reisner DS, Findl O, Petersen A, Fulton AB. The course of myopia in children with mild retinopathy of prematurity. Vision Res. 1995;35(9):1329-1335.

12. Wang J, Ren X, Shen L, Yanni SE, Leffler JN, Birch EE. Development of refractive error in individual children with regressed retinopathy of prematurity. Invest Ophthalmol Vis Sci. 2013;54(9):6018-6024.

13. Chen TC, Tsai TH, Shih YF, et al. Long-term evaluation of refractive status and optical components in eyes of children born prematurely. Invest Ophthalmol Vis Sci. 2010;51(12):6140-6148.

14. Fledelius HC, Fledelius C. Eye size in threshold retinopathy of prematurity, based on a Danish preterm infant series: early axial eye growth, pre- and postnatal aspects. Invest Ophthalmol Vis Sci. 2012;53(7):4177-4184.

15. Yang CS, Wang AG, Shih YF, Hsu WM. Long-term biometric optic components of diode laser-treated threshold retinopathy of prematurity at 9 years of age. Acta Ophthalmol. 2013;91(4):e276-e282.

16. Algawi K, Goggin M, O’Keefe M. Refractive outcome following diode laser versus cryotherapy for eyes with retinopathy of prematurity. $\mathrm{Br} J$ Ophthalmol. 1994;78(8):612-614.

17. Laws F, Laws D, Clark D. Cryotherapy and laser treatment for acute retinopathy of prematurity: refractive outcomes, a longitudinal study. Br J Ophthalmol. 1997;81(1):12-15.

18. McLoone EM, O'Keefe M, McLoone SF, Lanigan BM. Long-term refractive and biometric outcomes following diode laser therapy for retinopathy of prematurity. JAAPOS. 2006;10(5):454-459.

19. Quinn GE, Dobson V, Siatkowski R, et al. Does cryotherapy affect refractive error? Results from treated versus control eyes in the Cryotherapy for Retinopathy of Prematurity trial. Ophthalmology. 2001;108(2):343-347. 
20. Wu WC, Kuo HK, Yeh PT, Yang CM, Lai CC, Chen SN. An updated study of the use of bevacizumab in the treatment of patients with prethreshold retinopathy of prematurity in Taiwan. Am J Ophthalmol. 2013;155(1):150-158.e1.

21. Martínez-Castellanos MA, Schwartz S, Hernández-Rojas ML, et al. Long-term effect of antiangiogenic therapy for retinopathy of prematurity up to 5 years of follow-up. Retina. 2013;33(2):329-338.

22. Harder BC, Schlichtenbrede FC, von Baltz S, Jendritza W, Jendritza B, Jonas JB. Intravitreal bevacizumab for retinopathy of prematurity: refractive error results. Am J Ophthalmol. 2013;155(6):1119-1124.e1.

23. Chen YH, Chen SN, Lien RI, et al. Refractive errors after the use of bevacizumab for the treatment of retinopathy of prematurity: 2-year outcomes. Eye (Lond). 2014;28(9):1080-1086.

24. Salman AG, Said AM. Structural, visual and refractive outcomes of intravitreal aflibercept injection in high-risk prethreshold type 1 retinopathy of prematurity. Ophthalmic Res. 2015;53(1):15-20.

25. Isaac M, Mireskandari K, Tehrani N. Treatment of type 1 retinopathy of prematurity with bevacizumab versus laser. J AAPOS. 2015;19(2)140-144.

26. Kuo HK, Sun IT, Chung MY, Chen YH. Refractive error in patients with retinopathy of prematurity after laser photocoagulation or bevacizumab monotherapy. Ophthalmologica. 2015;234(4):211-217.

27. Chen SN, Lian I, Hwang YC, et al. Intravitreal anti-vascular endothelial growth factor treatment for retinopathy of prematurity: comparison between ranibizumab and bevacizumab. Retina. 2015;35(4): $667-674$.

28. Hwang CK, Hubbard GB, Hutchinson AK, Lambert SR. Outcomes after intravitreal bevacizumab versus laser photocoagulation for retinopathy of prematurity: a 5-year retrospective analysis. Ophthalmology. 2015;122(5):1008-1015.

29. Gunay M, Celik G, Gunay BO, Aktas A, Karatekin G, Ovali F. Evaluation of 2-year outcomes following intravitreal bevacizumab (IVB) for aggressive posterior retinopathy of prematurity. Arq Bras Oftalmol. 2015;78(5):300-3004.

30. Mintz-Hittner HA, Kennedy KA, Chuang AZ. Efficacy of intravitreal bevacizumab for stage $3+$ retinopathy of prematurity. $N$ Engl J Med. 2011;364(7):603-615

31. Early Treatment for Retinopathy of Prematurity Cooperative Group. Revised indications for the treatment of retinopathy of prematurity: results of the Early Treatment for Retinopathy of Prematurity randomized trial. Arch Ophthalmol. 2003;121(12):1684-1694.
32. Harder BC, von Baltz S, Schlichtenbrede FC, Jonas JB. Early refractive outcome after intravitreous bevacizumab for retinopathy of prematurity. Arch Ophthalmol. 2012;130(6):800-801.

33. Mintz-Hittner HA, Kretzer FL. Postnatal retinal vascularization in former preterm infants with retinopathy of prematurity. Ophthalmology. 1994;101(3):548-558.

34. Cryotherapy for Retinopathy of Prematurity Cooperative Group. Multicenter trial of cryotherapy for retinopathy of prematurity: preliminary results. Arch Ophthalmol. 1988;106(4):471-479.

35. Michael AJ, Pesin SR, Katz LJ, Tasman WS. Management of late-onset angle-closure glaucoma associated with retinopathy of prematurity. Ophthalmology. 1991;98(7):1093-1098.

36. Ritch R, Chang BM, Liebmann JM. Angle closure in younger patients. Ophthalmology. 2003;110(10):1880-1889.

37. Comparison of Age-Related Macular Degeneration Treatments Trials (CATT) Research Group, Martin DF, Maguire MG, et al. Ranibizumab and bevacizumab for neovascular age-related macular degeneration: two-year results. Ophthalmology. 2012;119(7):1388-1398.

38. Bakri SJ, Snyder MR, Reid JM, Pulido JS, Singh RJ. Pharmacokinetics of intravitreal bevacizumab (Avastin). Ophthalmology. 2007;114(5):855-859.

39. Bakri SJ, Snyder MR, Reid JM, Pulido JS, Ezzat MK, Singh RJ. Pharmacokinetics of intravitreal ranibizumab (Lucentis). Ophthalmology. 2007;114(12):2179-2182.

40. Sato T, Wada K, Arahori H, et al. Serum concentrations of bevacizumab (Avastin) and vascular endothelial growth factor in infants with retinopathy of prematurity. Am J Ophthalmol. 2012;153(2):327-333.

41. Matsuyama K, Ogata N, Matsuoka M, Wada M, Takahashi K, Nishimura T. Plasma levels of vascular endothelial growth factor and pigment epithelium-derived factor before and after intravitreal injection of bevacizumab. Br J Ophthalmol. 2010;94(9):1215-1218.

42. Tolentino M. Systemic and ocular safety of intravitreal antiVEGF therapies for ocular neovascular disease. Surv Ophthalmol. 2011;56:95-113.

43. Zhou Y, Jiang Y, Bai Y, Wen J, Chen L. Vascular endothelial growth factor plasma levels before and after treatment of retinopathy of prematurity with ranibizumab. Graefes Arch Clin Exp Ophthalmol. 2016;254(1):31-36.

44. Robinson GS, Ju M, Shih SC, et al. Nonvascular role for VEGF: VEGFR-1, 2 activity is critical for neural retinal development. FASEB J. 2001;15(7):1215-1217.
Eye and Brain

\section{Publish your work in this journal}

Eye and Brain is an international, peer-reviewed, open access journal focusing on clinical and experimental research in the field of neuroophthalmology. All aspects of patient care are addressed within the journal as well as basic research. Papers covering original research, basic science, clinical and epidemiological studies, reviews and evaluations,

\section{Dovepress}

guidelines, expert opinion and commentary, case reports and extended reports are welcome. The manuscript management system is completely online and includes a very quick and fair peer-review system, which is all easy to use. Visit http://www.dovepress.com/testimonials.php to read real quotes from published authors. 